\title{
A Framework for Investigating Foundation Year Students' Needs in General English in KAU: Needs Analysis Extended to Curriculum Development
}

\author{
Salameh Saleem Mahmoud \\ King Abdulaziz University, Saudi Arabia
}

\begin{abstract}
This research aims at describing a framework for investigating the general English language needs of foundation year students in King Abdul-Aziz University. Questions were raised about the skills and subskills in English language students should have upon finishing the foundation year and joining their prospected faculties in the university. Response came from two sources: Twelve representing faculties and 100 foundation year students. The methods used to obtain data were: semi-structured interviews and open discussion focus groups. A model of needs analysis based on the Learning -Centered Approach for Hutchinson and Waters (1987) was developed. The research findings are filtered and written into one final list. This research concludes by considering the implications of these findings and the importance of consulting the clients while designing or developing any curriculum.
\end{abstract}

Index Terms - clients, KAU, ELI, home team, visiting team, the new headway plus

\section{INTRODUCTION}

Needs analysis is acquiring more and more importance in the field of curriculum development and curriculum design. It is a device to know the learners' necessities, needs, and lacks in order to develop courses that have a reasonable content for exploitation in the classroom (Huchinson and Waters, 1987). Needs Analysis is therefore a process for identification and defining valid curriculum and instructional objectives. These objectives facilitate learning in an environment that is closely related to the real life situations of the student. It brings into focus the settings and roles that a learner is likely to face after he finishes his formal education. (Fatihi, 2003).

(Negretti, 2001; Kikuchi, 2004 Cowling, 2007; Kandil, 2009 cited in Ali \& Salih, (2013); Kaewpet, 2009) emphasized the necessity of needs analysis for the development of educational programs, syllabi and materials. They said that teaching everything is a loss of time and effort and may be you end up with confusion and your energy is not consumed in the right direction. Abbott, (1981) cited in Cowling (2007) described the case of teachers and course planners paying little or no attention to any concept of need as TENOR- teaching English for no obvious reason. In many cases syllabus design is a greatly overlooked area of course planning with many EFL schools and institutions relying on a textbook as the only syllabus regardless of what objectives students are going to achieve in the end. In other words, if students don't know what language they need in order to function effectively in the target situation, foreign language instructors cannot measure the gap between what students know at present and what they are required to know at the end of a certain program. As a result, freshmen in the majority of the Arab universities get stuck between the weak, language instruction that they received at school and the high expectations of their university professors. (Kandil, 2009) cited in Ali \& Salih, 2013).

\section{REVIEW OF LITERATURE}

Recently, researchers start to know the importance of needs analysis. They realized that it is not practical and it is not possible to teach the whole of a foreign language. Accordingly, it is advisable to focus on the reasons why learners need to learn the foreign language. This will enable professionals to cater for their learners' specific needs and save a lot of wasted time and effort. (Sysoyev, 2000; Songhori, 2008; Kayi, 2008; Kavaliauskiene, 2003) said that it is very important to start a course developing process with an analysis of the target group of students. Many problems in L2 classes are a result of teachers not paying attention to learners' interests, attitudes, expectations and learning habits and ignoring students as a source of essential information.

Although it was believed that needs analysis is rarely carried out in the general English classroom, (Seedhouse, 1995) mentioned an example of the analysis of psychological and social needs in a particular general English classroom. Such analysis can be useful with respect to problem- solving and a basis for designing aims, courses, and materials and to provide a link between needs, aims and materials and what actually occurs in the classroom. Valdez, (1999) suggested that grouping students after their needs have been collected enables teachers to modify the existing syllabus. Under 
language proficiency, a teacher makes a shift of emphasis for one of the skills on account of the other. A teacher can also know what teaching strategies are more appealing to his students, what kind of intelligence they have in common and what materials, teaching aids, activities are motivating to them.

In the literature about needs analysis, there are four models cited in (Kaewpet, 2009). These models are a Sociolinguistic Model (Munby, 1987), a Systemic Approach (Richterich and Chancerel 1977), A learning -Centered Approach (Huchinson and Waters, 1987), Learner-Centered Approach (Berwick, 1989; Brindly, 1989) and a Taskbased Approach (Long 2005a, 2005b). The sociolinguistic model means specifying target situations, communicative events, purposive domain, medium, mode, channel of communication, setting of communication and communicators. After all these are created, the communication needs are developed into a syllabus. The systemic approach considers the learners the center of attention whose present situations are thoroughly investigated. In this approach, the emergent nature of learner needs is taken into account; learner needs are approached by examining information before a course starts as well as during the course by the learners themselves and by the establishments such as their place of work and sponsoring bodies. Hutchinson and Waters, (1987) identified the following divisions of needs analysis: target needs and learning needs. Under target needs they included necessities that is, what the learner has to know in order to function effectively in the target situation, lacks mean the gap between the target proficiency and the existing proficiency and the learners' wants and their views about why they need language. The other main component is learning needs which explain how students will move from the starting point to the destination. In the learner centered approaches, three ways to look at learner needs are offered: perceived vs. felt needs; product vs. process oriented interpretations; and objective vs. subjective needs. Perceived needs are from the perspective of experts while felt needs are from the perspective of the learner. In the product-oriented interpretation, learner needs are viewed as the language that learners require in a target situation. In the process-oriented interpretation, the focus is on how individuals respond to their learning (Brindley, 1989). Finally, objective needs are explored prior to a course, whereas subjective needs are addressed while the course is underway.

(Cowling, 2007) mentioned four steps of data gathering. The first of which is discussion with the client. This is done through an informal interview set out to examine the reasons behind course needs as well as to gather more information about the target group in an attempt to understand what their English needs are. The second step is a semi-structured interview with the target group teachers. Interviewing these teachers may give useful insights into their students' language abilities. A third step is making interviews with the target group of students. Using target students as informers depends on how much knowledge they have about the objectives they are supposed to achieve. The last step is open-ended structured questionnaires for students to complete with their senior employees. These students have experience in the target situation as well as in previous English language courses.

\section{ReSEARCH MeTHODOLOGY}

\section{A. Question of the Study}

The question of the study is:

What are the English language needs of foundation year students in King Abdul-Aziz University?

\section{B. Procedures}

Adopting the Learning -Centered Approach (Huchinson and Waters, 1987) explained in the review of literature above, the process of needs analysis went through the following steps:

Step 1: Investigating the placement test of the students enrolling in the foundation year 1432/1433 in KAU to decide on their existing proficiency as soon as they arrive to ELI.

Step 2: Discussion with the clients. These are formal interviews with the home teams of the different faculties at the university to answer one major question: What are your expectations of the foundation year students with regard to English language skills and sub-skills after they finish the foundation year? To conduct this discussion, a list of questions reflecting the four skills and sub-skills was prepared to help the home team- the deans and selected instructors from faculties- answer the questions and talk about students' weaknesses and their expectations of the new students joining their faculties later. (See Appendix 1)

Step 3: Focus-groups for foundation year students who have already sat for the placement test. A list of questions that cover expected students' interests and preferences was prepared for the foundation year students to discuss. (See appendix 2)

Step 4: The outcome of the three steps above was filtered and arranged in a final list. This list is given to a sample of 10 instructors with varying qualifications and experiences who are asked to decide according to their experience which objective are achievable and realistic and which are not keeping in mind the level of students.

Step 5: The resulting list was compared to the lists of the Common European Framework lists for better writing of objectives.

\section{DisCUSSION OF RESULTS}

\section{A. Results of the Placement Test}


The results of the placement test were really alarming. Most of the students lack the basics of English language in the four English language skills. More than $87 \%$ of students fall in level one and level two according to the results of the placement test. This is due to the huge gap between the school education and the university education in KSA. The students who were able to reach level three and four were either graduates of private schools or they had the chance to accompany their parents while doing their higher studies in English speaking countries.

TABLE I

SHOWS THE NUMBER OF FOUNDATION YEAR SECTIONS AND THE TOTAL NUMBER OF STUDENTS IN EACH LEVEL AFTER CONDUCTING THE PLACEMENT TEST.

\begin{tabular}{|l|l|l|l|l|l|}
\hline & Level 1 & Level 2 & level 3 & Level 4 & Total \\
\hline No. of Sections & 155 & 35 & 20 & 8 & 218 \\
\hline No. of Students & 3100 & 700 & 400 & 160 & 4360 \\
\hline $\begin{array}{l}\text { Percentage of Students in } \\
\text { Each Level }\end{array}$ & $71,1 \%$ & $16 \%$ & $9,2 \%$ & $3,67 \%$ & $100 \%$ \\
\hline
\end{tabular}

Where level one students got $0 \%$ to $14 \%$, level two students got $15 \%$ to $29 \% \%$, level three students got $30 \%$ to $49 \%$ and level four students got $50 \%$ to $100 \%$ on the placement test.

\section{B. Results of Interviewing Home Teams at University Faculties}

While visiting the different faculties in King Abdulaziz University as the second step in doing the needs analysis, the home teams (the deans, vice deans or faculty members who responded to the interview about needs analysis) had nearly the same comments about the level of students who join their faculties after finishing the foundation year programs. They complained that students don't have the minimum of English that enables them to understand what professors talk about or to take notes for further revision after lectures. In addition, they said that students usually ask for the Arabic translation for the questions in quizzes and exams.

The faculties also have some peculiarities about the kind of English they need in their faculties. The Faculty of Pharmacology suggested that students in the foundation year can do seminars about topics related to their expected studies (Chemistry, Biology, Physics, medicine... etc. and that the English Language Institute (ELI) may invite specialists from these faculties in addition to a language specialist to assess students contributions. The Faculty of Applied Medical Sciences suggested teaching more general English and ESP and they summed up their suggestion in two points:

First, Teaching ESP within the English language load starting from level102 by dedicating three hours of the 18 hours- the weekly load of English classes in ELI- for ESP after grouping students according to their prospected fields. Second, students should take an intensive summer course in general English and ESP just after finishing the foundation year then pass a proficiency test as a pre requisite for joining their faculties. They also suggested using the internet as a teaching strategy to consolidate the four skills.

The Faculty of Medicine complained about the large number of students in their classes which minimizes the chances of interaction and suggested that ELI makes workshops for their staff on teaching strategies. The Faculty of Geology suggested sending their interested students back to ELI to attend classes. In addition to their complaints about students' weakness in the four main skills. The faculty of engineering management suggested that students should be taught how to write a research paper including rephrasing, documenting references, analyzing, browsing the internet for articles relevant to a topic of study and recommending solutions for problems. The faculty of computing suggested getting a five hundred and above result on the TOEFL as a precondition for joining the faculty of computing.

The leader and the members of the visiting team (the Needs Analysis Committee coming from the English Language Institute) explained to the home teams what they are doing in ELI and how much ambitious their plans of teaching and assessment are and their visits to their respected faculties are enough proof that they are very much concerned about providing students with the necessary skills. The visiting team also explained that the weakness in some sub skills might be attributed to reasons like students' motivation in general that is not as it used to be. In fact, this is not a local or even national problem and something should be done to increase students' motivation. Another reason is that most of the teaching in other courses in the foundation year like Chemistry, Biology, Statistics and Physics is done in Arabic except for the terminology which undermines the plans of ELI administration and loses much of their efforts instead of supporting them and accelerating getting to their ultimate goals.

A third reason is that the teaching strategies followed by instructors in the faculties after the foundation year don't guarantee the right extension and consolidation of what the staff in ELI are doing. This appears in the following practices: First, instructors follow a short cut to communicate their ideas to students; that is, they translate into Arabic which makes students wait for their translation and saves them the effort of trying to understand or think in English. Furthermore, in some faculties the whole book is minimized to a small leaflet instead of referring students to the main book and encouraging them to read not only the book but other references and articles. Moreover, The testing system follows the MCQ type which makes students and instructors test oriented and less or even not interested in any writing because all what they need is to circle the correct answer.

To sum up, it appears from the comments and suggestions of the home teams in the faculties that students coming from the foundation year lack the minimum of the four English language skills and sub skills that enables them to 
manage throughout their studies. They need listening skills and sub skills in order to understand and take notes as their professors are explaining. They also need speaking skills and sub skills to give presentation and to interact with their teachers and classmates. Writing is a very important skill for them as they take notes, answer questions in exams and quizzes and write reports and assignments. Finally they need to focus on the reading skills and sub skills as university life depends mainly on different sources other than one book or notebook to memorize.

\section{Results of Students' Focus Groups}

While asking foundation year students at KAU a group of questions in focus groups about the English language teaching process and about the syllabus they are currently using ( See Appendix 2), their answers were mainly focused on the implementation of the syllabus, the activities, the shift of emphasis on the four skills and other formalities. The details below show the different opinions of students in the focus groups.

\section{Question One}

What do you like most about being in your English class?

Most of the students liked the idea of portfolio where students keep their contributions throughout the semester, then finally given a grade for their regular participation and improvement. Reading circles where students are given a story to prepare and assigned different roles to discuss it in the class is an activity that most students appreciated. Projectors, smart boards and other teaching aids used in the class in addition to having not more than twenty students in the class are among the things they pointed out during the discussion.

\section{Question Two}

What haven't you enjoyed in your English Class?

The 11:00 to 4:00 Sunday and Tuesday time slots are too long and boring for most of the students. They also complained about the big amount of copying in portfolio assignments and the writing booklet- a handout they fill weekly in order to develop their writing. The inconsistency in applying the classroom code, the big number of tests per module, the rare use of teaching aids and technology are among the things students mentioned as inconveniences in the English language classroom. All the students agreed unanimously that the English classes are boring because they lack the variety of activities, group work, pair work, role playing which turns the class into a traditional lecture.

\section{Question Three}

Do you think your English has improved? How much? What has improved most?

Most students said that they have improved but it is still below expectations. They also said that listening and speaking need to be given special interest as they are a problem for most of the students.

\section{Question Four}

What hasn't improved? Why not?

The majority of the students in the focus groups refer their weakness in writing and listening to the following comments: writing needs more practice, listening is too fast and difficult to understand due to big number of students in the class, students are usually not involved in classroom activities, teachers don't correct students' pronunciation mistakes.

\section{Question Five}

What changes would you like to see in the way English is taught in ELI?

Most of the students have concerns about listening and they suggested giving more attention and focus to this skill. They also recommended creating a website for listening in addition to making a listening lab for students to practice. Their second comment was about teaching strategies, the weekly load and the classroom environment. They thought that shorter time slots per day, longer period for each module, offering an additional course in summer may be solutions to some of their problems. They also suggested that teachers prepare them for the TOEFL exam. The third suggestion was about the placement test, they think that the MCQ questions allow chance for guessing and cheating and may end with displacement to many students.

\section{Question Six}

If there were one thing you could change about the English class, what would it be?

Almost every student has different opinion about what to change in the English class. Writing assessment, the instructor, moving from one section to the other are among the things they want to have a word in doing. They also want to be consulted while choosing the syllabus; they want materials about everyday English. They are not happy with the way speaking is tested where instructors test students individually, they suggested that an open discussion suits them more and encourages them to talk. Surprisingly, they want more activities in the class which makes it less boring. The big number of students in the class was a common complaint for most of the students.

\section{Question Seven}

What do you like or dislike about New Headway Plus- The syllabus they are currently using in ELI?

Upon asking the students in the focus group what they like about the book they said that there is a variety of topics and it contains important themes about different parts of the world. The four books of the New Headway Plus suit the four levels used in Eli. The quality of paper and the colors are great. It has a grammar reference, audio material and a very rich workbook. On the other hand, most of the students said that the examples and texts have nothing to do with the Saudi culture. Some of them also protested about the pictures used in the book as the Saudi culture has a certain peculiarity even among the Arab countries; any naked part of a woman's body is unaccepted. In addition, there are 
sentences about boyfriends, girl friends, kissing and dating. Level one students found the New Headway Plus beginners a big challenge for them. The listening content is too fast for students to understand and the activities in the syllabus don't lend themselves to pair work or group work.

\section{CONCLUSION}

In fact, there are many approaches to needs analysis, but I found Hutchinson and Waters' learning -Centered Approach the most practical and easy to use. Although the home teams- deans, vice deans and members of the staff- in the faculties were very welcoming and cooperative, they were at the same time very unrealistic in their demands. They want the students in the foundation year to move from almost zero to competent students who are able to score 500 in the TOEFL and to be able to write a research paper. These demands are impossible to achieve in one year taking into consideration the lack of motivation on one hand and the heavy load students have to finish in the foundation year on the other hand. Students not only study English, they also study Chemistry, Biology, Statistics, Math and communication skills.

Taking all these conditions into consideration, the demands had to be refined and written in a more realistic way that matches the time limits and the very modest level of the students coming from schools to join the foundation year.

\section{RECOMMENDATIONS}

Looking at the results of the interviews of home teams in the twelve representing faculties in KAU and focus groups of foundation year students, the researcher has these recommendations:

1. Decision makers and educational leaders should pay more attention to needs analysis as the first unavoidable step before choosing any syllabus.

2. Students interests and preferences, the teaching environment or the teaching strategies should be taken into consideration.

3. Although the main concern in the foundation year is teach a common core of English Language skills, there is no harm if teachers give some ESP material if they find that a certain group of students is so confident about joining a certain faculty.

4. The content and the mechanism of the placement test in Eli should be reconsidered so that it becomes more reliable and valid.

5. ELI managing staff should try their best to have not more than twenty students in each classroom.

6. The ELI in KAU should take the skills and the subs kills in appendix 3 in addition to the results of the focus groups into consideration while choosing or developing any syllabus.

\section{ACKNOWLEDGEMENT}

I would like to thank the managing team of ELI at King Abdulaziz University for their cooperation and technical support which made my job easy. I would also like to extend my gratitude to Mr Simon Best- the Head of the Curriculum Committee and his team for their invaluable contribution in conducting the focus groups through an ongoing well-done professional process.

\section{APPENDIX (1)}

A List of Questions for Faculties in KAU Meant to Help the Home Team and the Visiting Team Conduct the Interviews.

Below are suggested objectives for you to look at while asking the home team. If any one of the objectives agrees with the home members' suggestions, just tick yes. If they suggest any new objectives, skills, sub skills, please write them under OTHER SUGGESTIONS. I hope you good luck and well done job. 


\begin{tabular}{|c|c|c|c|c|c|}
\hline SKILL & No. & SUGGESTED OBJECTIVES & YES & NO & $\begin{array}{l}\text { OTHER } \\
\text { SUGGESTIONS }\end{array}$ \\
\hline \multirow[t]{6}{*}{ LISTENING } & 1 & $\begin{array}{l}\text { What listening sub skills do your students need? } \\
\text { Do they understand the general meaning and specific } \\
\text { details of a lecture or a presentation given in English } \\
\text { (native or non-native) about their field of study? }\end{array}$ & & & \\
\hline & 2 & $\begin{array}{l}\text { Do they understand and respond to your questions } \\
\text { during the class? }\end{array}$ & & & \\
\hline & 3 & $\begin{array}{l}\text { Do they catch the main idea of a TV program or any } \\
\text { recorded audio material on topics related to their study? }\end{array}$ & & & \\
\hline & 4 & $\begin{array}{l}\text { Do they understand and respond to instructions in a lab } \\
\text { or workshop related to their field? }\end{array}$ & & & \\
\hline & 5 & $\begin{array}{l}\text { Are they able to work out the meaning of unknown } \\
\text { word(s) in a familiar context? }\end{array}$ & & & \\
\hline & 6 & $\begin{array}{l}\text { Are they able to take notes while a lecture in English is } \\
\text { being delivered? How much out of } 100 \% \text { ? }\end{array}$ & & & \\
\hline \multirow[t]{5}{*}{ READING } & 1 & $\begin{array}{l}\text { What reading sub-skills do you want your students } \\
\text { to have? } \\
\text { Are they able to find and understand relevant } \\
\text { information in everyday material (brochures, short } \\
\text { official documents, catalogue, short reports, job } \\
\text { adverts?) }\end{array}$ & & & \\
\hline & 2 & $\begin{array}{l}\text { Are they able to skim and scan texts for general or } \\
\text { specific information? }\end{array}$ & & & \\
\hline & 3 & $\begin{array}{l}\text { Can they read a map to find a place in a city or a room } \\
\text { in a building, or a country or a city in the world map? }\end{array}$ & & & \\
\hline & 4 & Can they summarize a short text of a familiar nature? & & & \\
\hline & 5 & $\begin{array}{l}\text { Are they able to follow clear routine instructions ( for a } \\
\text { game, recipe, using equipment, or installing computer } \\
\text { software? }\end{array}$ & & & \\
\hline \multirow[t]{8}{*}{ SPEAKING } & 1 & $\begin{array}{l}\text { What speaking sub skills do you want your students } \\
\text { to have? } \\
\text { Can they receive and respond to a phone conversation } \\
\text { of familiar nature spoken at normal speed? }\end{array}$ & & & \\
\hline & 2 & $\begin{array}{l}\text { Are they able to agree and disagree politely, exchange } \\
\text { personal opinions, compare and contrast alternatives? }\end{array}$ & & & \\
\hline & 3 & $\begin{array}{l}\text { Can they express and respond to feelings and attitudes } \\
\text { (e.g. surprise, happiness, sadness, interest, uncertainty, } \\
\text { indifference?) }\end{array}$ & & & \\
\hline & 4 & $\begin{array}{l}\text { Can they ask politely about things they didn't } \\
\text { understand or need more clarification? }\end{array}$ & & & \\
\hline & 5 & $\begin{array}{l}\text { Can they give a short and straightforward prepared } \\
\text { presentation on a chosen topic in their academic or } \\
\text { professional field in a reasonably clear and precise } \\
\text { manner? }\end{array}$ & & & \\
\hline & 6 & $\begin{array}{l}\text { Can they repeat back what is said to check if they have } \\
\text { understood? }\end{array}$ & & & \\
\hline & 7 & $\begin{array}{l}\text { Can they start, maintain and close simple face-to-face } \\
\text { conversation on topics that are familiar, of personal } \\
\text { interest or related to their study? }\end{array}$ & & & \\
\hline & 8 & & & & \\
\hline \multirow[t]{6}{*}{ WRITING } & 1 & $\begin{array}{l}\text { What writing sub skills do you want your students } \\
\text { to have? } \\
\text { Can they write their C.V in a summary form? }\end{array}$ & & & \\
\hline & 2 & $\begin{array}{l}\text { Can they describe or write a report about an event like: } \\
\text { a recent trip, an experiment in the lab, a workshop they } \\
\text { attended recently, a lecture related to their study? }\end{array}$ & & & \\
\hline & 3 & $\begin{array}{l}\text { Can they fill an application for a job or a bank or a } \\
\text { travel agency or joining an institution like a university, } \\
\text { institute...etc? }\end{array}$ & & & \\
\hline & 4 & $\begin{array}{l}\text { Can they write a letter ( formal / informal ) to } \\
\text { complain, order, apologize, recommend, inquire, } \\
\text { invite ...etc? }\end{array}$ & & & \\
\hline & 5 & $\begin{array}{l}\text { Can they write a short e-mail to communicate a } \\
\text { message? }\end{array}$ & & & \\
\hline & 6 & $\begin{array}{l}\text { Can they write a summary of a short narrative given at } \\
\text { normal speed? }\end{array}$ & & & \\
\hline
\end{tabular}

It is also a good idea to ask these questions:

1. Is English the main instructional language? In all courses, most courses, senior courses only, a course or two?

2. Is the main text book in English? In all courses, most courses, senior courses only, a course or two? 
3. Is the language of tests English or Arabic?

4. Are there other books or notes suggested or provided to the students as alternatives for textbooks? If yes, Are these in English?

5. Are the references, learning resources, self learning materials important during his study or after his graduation available mostly in English?

6. Number (or percentage) of non-Arabic speaking faculty.

APPENDIX (2)

The Questions Used for the Foundation Year Students’ Focus Groups

\begin{tabular}{|l|l|}
\hline No. & Question \\
\hline 1 & What do you like most about being in your English class? \\
\hline 2 & What haven't you enjoyed in your English Class? \\
\hline 3 & Do you think your English has improved? How much? What has improved most? \\
\hline 4 & What hasn't improved? Why not? \\
\hline 5 & What changes would you like to see in the way English is taught in ELI? \\
\hline 6 & If there were one thing you could change about the English class, what would it be? \\
\hline 7 & What do you like or dislike about New Headway Plus? \\
\hline
\end{tabular}

\section{APPENDIX (3)}

Students Outcomes Emerging from the Interviews with Faculties and Students' Focus Groups By the end of the foundation year students should be able to:

\begin{tabular}{|c|c|c|}
\hline SKILLS & No. & OBJECTIVES \\
\hline \multirow[t]{6}{*}{ LISTENING } & 1 & interpret standard spoken language on both familiar and unfamiliar topics in everyday situations. \\
\hline & 2 & $\begin{array}{l}\text { identify information, ideas and opinions in extended speech and follow complex lines of argument, provided the } \\
\text { topic is reasonably familiar and/or related to their study and delivered in standard spoken language. }\end{array}$ \\
\hline & 3 & $\begin{array}{l}\text { identify the overall meaning of most films, TV news programs, documentaries, interviews, chat shows in standard } \\
\text { speech. }\end{array}$ \\
\hline & 4 & $\begin{array}{l}\text { interpret complex technical information, such as operating instructions, specifications for familiar products and } \\
\text { services. }\end{array}$ \\
\hline & 5 & $\begin{array}{l}\text { interpret a wide range of recorded and broadcast audio material, including some non-standard usage and identify } \\
\text { finer points of detail including implicit attitudes and relationships between speakers. }\end{array}$ \\
\hline & 6 & practice taking notes and summarizing listening texts. \\
\hline \multirow[t]{7}{*}{ READING } & 1 & interpret in details texts related to their specialist or general interests. \\
\hline & 2 & interpret articles on a range of specialized topics using a dictionary and other appropriate reference resources. \\
\hline & 3 & $\begin{array}{l}\text { examine the content and relevance of news items, articles and reports on a variety of topics connected with their } \\
\text { interests or study, and decide if a closer reading is worthwhile. }\end{array}$ \\
\hline & 4 & $\begin{array}{l}\text { apply reading strategies and activities like skimming, scanning, prediction, providing ellipsis, choosing the suitable } \\
\text { title, knowing the writer's attitude, doing a cloze test... }\end{array}$ \\
\hline & 5 & $\begin{array}{l}\text { interpret lengthy instructions (e.g. in a user manual for a TV or technical equipment used in their work), as long as } \\
\text { they can reread difficult sections. }\end{array}$ \\
\hline & 6 & $\begin{array}{l}\text { distinguish and identify information, ideas and opinions from highly specialized texts in my own field, e.g. } \\
\text { research reports. }\end{array}$ \\
\hline & 7 & $\begin{array}{l}\text { apply word attack skills (parts of speech, derivations, suffixes, prefixes, grammar rules and context clues) to } \\
\text { discover the meanings of new vocabulary items. }\end{array}$ \\
\hline \multirow[t]{7}{*}{ SPEAKING } & 1 & $\begin{array}{l}\text { create, maintain and close a simple face-to-face conversation on any topic of personal interest or related to study, } \\
\text { with generally appropriate use of formal or informal language. }\end{array}$ \\
\hline & 2 & $\begin{array}{l}\text { employ most practical tasks in everyday situations (e.g. making telephone inquiries, answering telephone calls, } \\
\text { asking for a refund or replacement, negotiating purchase, asking for and giving directions ...) }\end{array}$ \\
\hline & 3 & express and respond to feelings and attitudes (e.g. surprise, happiness, sadness, interest, uncertainty, indifference). \\
\hline & 4 & $\begin{array}{l}\text { practice agreeing and disagreeing politely, exchange personal opinions, discuss what to do next, compare and } \\
\text { contrast alternatives. }\end{array}$ \\
\hline & 5 & describe familiar subjects related to their work, study or interests. \\
\hline & 6 & produce a presentation on a chosen topic in their academic or professional field in a clear and precise manner \\
\hline & 7 & construct and understand messages while talking to native speakers of English \\
\hline \multirow[t]{7}{*}{ WRITING } & 1 & complete their CVs \\
\hline & 2 & $\begin{array}{l}\text { describe an event (e.g. a recent business trip or holiday, accident, an experiment in the lab, history of patients, a } \\
\text { prescription, a recipe, a report, a diagnosis ...) }\end{array}$ \\
\hline & 3 & $\begin{array}{l}\text { create and respond to e-mails in a standard format communicating inquiries and factual information, explaining } \\
\text { problems. }\end{array}$ \\
\hline & 4 & $\begin{array}{l}\text { create standard letters giving or requesting detailed information (e.g. replying to an advertisement, applying for a } \\
\text { job). }\end{array}$ \\
\hline & 5 & create personal letters giving news, describing experiences and impressions, and expressing feelings. \\
\hline & 6 & produce a well -developed essay nearly free of spelling and grammar mistakes on a given topic. \\
\hline & 7 & $\begin{array}{l}\text { Write a reflection about a reading, fill a (KWL) table before and after studying a certain topic, write take a stand } \\
\text { assignments based on reading passages, create a summary of a story or a reading text. }\end{array}$ \\
\hline
\end{tabular}




\section{REFERENCES}

[1] Ali, H. I. H. and Salih, R. A. (2013). Perceived Views of Language Teachers on the Use of Needs Analysis in ESP Materials Writing. English Language Teaching; Vol. 6, No. 3, pp 11-19

[2] Cowling, J. D. (2007). Needs Analysis: Planning A syllabus for a Series of Intensive Workplace Courses at a Leading Japanese Company. English for Specific Purposes 26, pp: 426-442.

[3] Fatihi, A. R. (2003). The Role of Needs Analysis in ESL Program Design, SOUTH ASIAN LANGUAGE REVIEW,VOL.XIII, Nos.1\&2, January-June,2003, pp 40-59

[4] Hutchinson, T., \& Waters, A. (1987). English for specific purposes: A learning-centred approach. Cambridge: Cambridge University Press.

[5] Kaewpet, C. (2009). A Framework for Investigating Learner Needs: Needs Analysis Extended to Curriculum Development. Electronic Journal of Foreign Language Teaching, Vol. 6, No. 2, pp. 209-220

[6] Kayi, H. (2008). Developing an ESL Curriculum Based on Needs and Situation Analysis: A Case Study. Journal of Language and Linguistic Studies. Vol.4, No.1, April 2008, pp 29-49

[7] Kavaliauskiene, G. and Daiva U. (2003). Ongoing Needs Analysis as a Factor to Successful Language Learning. Journal of Language and Learning. Vol.1, No. 1, pp: 14-23

[8] Kikuchi, K. (2004). Triangulating Perceptions of learners' needs: An Alternate Way of Conducting Needs Analysis. The Interface between Inter language, Pragmatics and Assessment: Proceedings of the $3^{\text {rd }}$ Annual JALT Pan- SIG Conference. Tokyo Keizai

[9] Negretti, R. (2001). Needs Analysis: Academic Writing for International Graduate Students. http: www.sls.hawaii.edu/ELInternet/negretti.html,2012.

[10] Seedhouse, P. (1995). Needs Analysis and the General English Classroom. ELT Journal, Volume49 (1). Oxford University Press.

[11] Songhori, M. H. (2008). Introduction to Needs Analysis. English for Specific purposes World, Issue 4. www.esp_world info, pp: $1-25$

[12] Sysoyev, P. V. (2000). Developing an English for Specific Purposes Course Using a Learner Centered Approach: A Russian Experience. The Internet TESOL Journal, Vol.6. No. 3, http://iteslj.org/Techniques/Sysoyev-ESP.html.

[13] Valdez, M. G. (1999). How Learners' Needs Affect Syllabus Design. English Teaching Forum. Vol.37, No. 1. www.paulnoll.com/Books/Clear-English/English-3000-commom-words.html, 2013.

Salameh Saleem Mahmoud was born in Palestine in 1963. His educational background starts with the school life from $1^{\text {st }}$ to $12^{\text {th }}$ in one of the villages in Palestine then the BA in General English at Al-Najah National University in Nablus-Palestine in 1986. Then after he moved to Jordan to work as a teacher, the author joined the University of Jordan in Amman-Jordan to get his High Diploma and his MA in Teaching English as a Foreign Language in 1995 and 2000 respectively. Two years later, he joined Amman Arab University in Amman-Jordan for his PhD in Curriculum and Teaching. The author's major field of study is teaching and curriculum design. All the his experience is in teaching and coordination. Between 1986 and 1990 he was a teacher in public schools in Amman/Jordan. Then he moved to the private sector- I mean private schools- to work as a teacher, coordinator and head of an English department. During the period 1990 to 2005, the author got his three last certificates in addition to keeping his job as a teacher, coordinator and head of an English department, in addition to a part time lecturer at Al-Balqa Uni. in Amman. In 2005 he moved to KSA as a language instructor in King Abdulaziz Uni. in Jeddah/KSA. During this period, he participated in many committees like the testing committee, the curriculum committee, the needs analysis committee where this paper was born. In the middle of last year, he was chosen by the dean of the Faculty of Engineering to supervise, edit and monitor graduate students' proposals and he is still there.

Concerning publication, the author admits that he wakes up late first in his higher studies and second in his research for reasons out of his hand. Anyway, to arrive late is better than not to arrive at all. In the last two years, he has already published three articles and "Needs Analysis for Curriculum Design" is his fourth and currently working on the fifth. His first article "The Effect of Using L1 in the L2 classroom on Foundation Year Students' Achievement in General English at King Abdulaziz University." was published by David Publishing Company in 2012. The second article "The Impact of Using SMS in the EFL Classroom on Students" Achievement in Writing And Speaking," was published by the Center for Promoting Ideas-USA. The third article "Integrating Mobile Learning in the EFL Classroom..." was published by the English Language Teaching Journal in Canada. To sum up, the author's main concern in his research is how to integrate the new technology in the EFL classroom.

Finally, Dr Mahmoud has participated in many local committees inside King Abdulaziz University and has given many workshops and seminars about teaching methods in Jordan and in KSA. ESP has been one of the author's concerns; he has already finished a book "English for Art and Design" which is now used in a big college in Jeddah. 